\title{
Unresolved Issue
}

National Cancer Institute

\section{Source}

National Cancer Institute. Unresolved Issue. NCI Thesaurus. Code C42869.

Any problem that remains unresolved regarding proper documentation of the Administered Item. 